\title{
EVALUASI PEMBELAJARAN PENDIDIKAN AGAMA ISLAM DAN IMPLIKASINYA TERHADAP MOTIVASI BELAJAR PESERTA DIDIK DI MTS NU BANAT KUDUS
}

\author{
M. Chusnuts Tsawab ${ }^{1 *}$, Uswatun Khasanah², Nor Faelashofa Afrida ${ }^{3}$, Maisyanah4 \\ ${ }^{1}$ IAIN Kudus, Kota Kudus, Indonesia, Email: ctsawab999@gmail.com \\ ${ }^{2}$ IAIN Kudus, Kota Kudus, Indonesia, Email: uswah04.kds@gmail.com \\ 3 IAIN Kudus, Kota Kudus, Indonesia, Email: nor.faelashofa18@gmail.com \\ ${ }^{4}$ IAIN Kudus, Kota Kudus, Indonesia, Email: mayaarifin@iainkudus.ac.id
}

\begin{abstract}
ABSTRAK
Motivasi belajar merupakan aspek yang sangat penting sebagai langkah untuk meningkatkan prestasi belajar peserta didik. Dalam konteks ini, pendidik mempunyai peran dan tanggung jawab yang sangat besar dalam menumbuhkan motivasi belajar peserta didiknya, yakni salah satunya dengan memberikan evaluasi pembelajaran. Tujuannya untuk mengetahui apakah evaluasi pembelajaran yang telah dilakukan selama ini mampu mempengaruhi motivasi belajar peserta didik MTs NU Banat Kudus secara signifikan. Penelitian dilakukan menggunakan rancangan kualitatif dengan metode studi kasus yang diperoleh dari hasil wawancara. Hasil penelitian menunjukkan bahwa evaluasi pembelajaran mampu memeberikan pengaruh yang sangat besar terhadap motivasi peserta didik dalam belajar. Sehingga dapat disimpulkan bahwa evaluasi pembelajaran adalah komponen penting dari pendidikan, karena sangat berpengaruh terhadap peningkatan motivasi belajar peserta didik dalam meningkatkan volume dan strategi belajar.

Kata Kunci

Evaluasi Pembelajaran, Pendidikan Agama Islam, Motivasi Belajar
\end{abstract}

\begin{abstract}
Learning motivation is a very important aspect as a step to improve students' learning achievement. In this context, educators have a very big role and responsibility in fostering students' learning motivation, which is one of them by providing an evaluation of learning. The aim is to find out whether the
\end{abstract}


evaluation of learning that has been carried out so far is able to significantly influence the motivation to learn MTs NU Banat Kudus students. The study was conducted using a qualitative design with a case study method obtained from the results of the interview. The results showed that the evaluation of learning is able to give a very big influence on the motivation of students in learning. So it can be concluded that the evaluation of learning is an important component of education, because it is very influential on increasing student learning motivation in increasing volume and learning strategies.

Keywords

Evaluation of Learning, Islamic Education, Learning Motivation

Received : 06-07-2020

Revised : 25-07-2020

Accepted : 26-08-2020

Copyright (c) 2020 Tsawab, Khasanah, Afrida, Maisyanah

\section{PENDAHULUAN}

Pendidikan merupakan salah satu indikator maju atau tidaknya Negara tersebut, karena masa depan sebuah Negara dikatakan aman apabila berada ditengah masyarakat yang berpendidikan. Pendidikan adalah suatu bentuk upaya dari manusia guna mendewasakan peserta didik sehingga mampu menjadi manusia yang mandiri serta bertanggung jawab untuk dirinya sendiri, orang lain, maupun makhluk di sekitarnya. Upaya pendewasaan peserta didik memiliki makna yang luas, seperti; transfer pengetahuan dan keterampilan, bimbingan dan arahan penguasaan pengetahuan, keterampilan dan pembinaan kepribadian, sikap moral dan sebagainya. Peserta didik bukan hanya sebagai manusia muda yang 94 mengalami proses pertumbuhan dan perkembangan, melainkan juga sebagai manusia dewasa yang sedang mempelajari pengetahuan serta keterampilan. (Ahmad Syar'i, 2005:4). Menurut UU No. 20 tahun 2003 mengenai sistem pendidikan nasional, bahwa definisi pendidikan merupakan upaya yang dilakukan untuk mewujudkan suatu kegiatan pembelajaran aktif dalam meningkatkan potensi dan keterampilan peserta didik.

Motivasi belajar memiliki pengaruh dalam peningkatan prestasi peserta didik. Hal ini menunjukkan bahwa pendidik memiliki peran dan kewajiban yang sangat penting dalam menciptakan motivasi belajar peserta didik, salah satunya seperti melakukan evaluasi pembelajaran. Berdasarkan uraian 
diatas dapat diketahui bahwa tujuan harus dimiliki dalam tindakan memotivasi. Oleh karenanya setiap orang yang akan memberikan motivasi harus memahami dan mengenal berbagai hal terkait orang yang akan diberikan motivasi. Aktivitas siswa dalam pembelajaran sangatlah penting dan menjadi faktor utama dalam terwujudnya tujuan pembelajaran, dalam hal ini sudah barang tentu peran guru juga sangatlah penting. Terdapat banyak permasalahan yang belum memiliki titik temu, salah satunya mengenai bagaimana seorang pendidik mampu menumbuhkan suatu motivasi bagi peserta didik. Maka motivasi memiliki andil terhadap proses belajar peserta didik agar adanya evaluasi mampu menghasilkan output yang baik.

Dalam dunia pendidikan apabila proses evaluasi tidak dilakukan maka akan berakibat pada output ataupun kualitas dari peserta didik tersebut, yakni tidak maksimalnya pemahaman peserta didik terhadap materi yang diajarkan, serta tujuan yang diharapkan dari sebuah lembaga pendidikan tersebut tidak dapat tercapai dengan maksimal.
Adapun dalam perkembangannya masih dapat ditemukan beberapa pendidik yang belum mampu memaksimalkan kegiatan evaluasi pembelajaran, yakni masih terdapatnya guru yang tidak melakukan perubahan dalam proses pembelajarannya, baik itu dalam penyampaian materi maupun dalam kegiatan evaluasinya. Padahal sudah terlihat dengan jelas bahwa peserta didik belum mampu menyerap seluruh materi yang disampaikan sehingga nilai yang dihasilkan dalam proses pembelajaran tersebut masih rendah. Selain itu, yang sering kita jumpai adalah guru menaikkan nilai raport peserta didik agar tuntas semua dalam mencapai nilai KKM (Kriteria Ketuntasan Minimal) padahal dalam kenyataannya, masih ada peserta didik yang nilainya berada dibawah batas yang telah ditentukan. Sehingga nilai yang diterima peserta didik bukan nilai asli dari hasil pembelajaran yang telah dilakukan. MTs NU Banat Kudus, merupakan salah satu lembaga yang dapat kami jadikan sebagai tolak ukur dalam penerapan pembelajaran, dalam hal ini MTs NU 
Banat Kudus pun menerapkan sistem evaluasi dalam proses pembelajarannya, guna mengukur atau mengetahui pemahaman peserta didik. Salah satu penyebab terjadinya permasalahan mengenai pemahaman peserta didik diatas adalah kurang optimalnya pelaksanaan evaluasi terkait motivasi peserta didik di MTs NU Banat Kudus dalam hal belajar. Adapun tujuannya yaitu Untuk mengetahui apakah evaluasi pembelajaran pendidikan agama Islam dapat meningkatkan motivasi belajar peserta didik di MTs NU Banat Kudus. seorang guru ikut andil dan berperan penting terhadap motivasi belajar peserta didik, dimana pendidik berperan dalam menumbuhkan atau memacu para peserta didik memiliki keinginan untuk meningkatkan prestasinya dalam upaya mencapai hasil output seperti yang telah diharapkan.

Dalam artikel ini kami menggunakan sudut pandang keislaman sebagai penguat tulisan dalam artikel, karena dalam artikel ini sangat relevan apabila dikaitkan dengan ilmu keislaman yang ada, karena ilmu keislaman bersumber dari Al-Qur'an yang dimana akan terus relevan dipakai dimanapun dan kapanpun zamannya. Selain itu alasan penggunaan ilmu keislaman ini adalah sebagai patokan atau berpijak agar tulisan artikel ini tidak melenceng dari ajaran agama islam yang telah ditetapkan. Berdasarkan pemaparan diatas, penulis tertarik untuk membahas perihal evaluasi pembelajaran pendidikan islam beserta pengaruhnya terkait motivasi belajar peserta didik di MTs NU Banat Kudus. Diharapkan pembahasan ini mampu menjadi solusi untuk menyelesaikan salah satu permasalahan yang terdapat di dunia pendidikan, terutama terkait proses evaluasi pembelajaran dan untuk meluruskan presepsi para pendidik maupun calon pendidik dalam memaknai apa itu kegiatan evaluasi yang diterapkan dalam sebuah lembaga agar meningkatkan motivasi belajar peserta didik.

\section{METODOLOGI PENELITIAN}

Penelitian ini adalah penelitian kualitatif yakni sebuah penelitian yang memanfaatkan lingkungan alamiah sebagai sumber data langsung. Dalam hal ini peneliti 
berusaha mencari data-data dengan mengambil berbagai sumber yang terkait dengan fokus penelitian. Penulis menggunakan berbagai sumber literature baik bersumber dari buku, jurnal, hasil seminar serta hasil diskusi bersama ahli yang relevan. Selanjutnya dilakukan analisis terkait data yang telah terkumpul.

$\begin{array}{clc}\text { Jadi } & \text { penelitian } & \text { kualitatif } \\ \text { deskriptif } & \text { merupakan } & \text { penelitian }\end{array}$
yang datanya bersumber langsung dari lingkungan alamiah untuk acuan penarikan konsep dan makna melalui pemaparan deskriptif analitik, dan lebih mengutamakan proses terbentuknya tingkah laku dalam situasi alam.

Adapun sumber data dalam penelitian ini yaitu :

1. Sumber Data Primer

Data primer merupakan data yang langsung dikumpulkan dari hasil wawancara langsung kepada salah satu guru yang melakukan evaluasi di sekolah MTs NU Banat Kudus yaitu ibu Dra. Hj. Dianah, M.Pd.I. pengampu mata pelajaran Al-
Qur'an Hadits Kelas VIII dan IX MTs NU Banat Kudus.

2. Sumber Data Sekunder.

Sumber data sekunder yang digunakan sebagai acuan penelitian ini, didapat dari beberapa literatur terkait seperti dari buku-buku, dan jurnaljurnal yang sesuai dengan topik pembahasan artikel ini.

\section{HASIL DAN PEMBAHASAN}

\section{A. Evaluasi Pembelajaran}

\section{Definisi Evaluasi Pembelajaran}

Evaluasi secara etimologi berasal dari bahasa Inggris yaitu evaluation (penaksiran dan penilaian) sedangkan dalam bahasa Arab berasal dari kata "Imtihan" yang artinya khataman dan ujian yaitu sebuah cara yang digunakan untuk menilai hasil suatu kegiatan. Edwind wandt dan Gerald W. Brown dalam buku essensial of education evaluatio mengatakan evaluasi secara terminologi adalah suatu tindakan atau kegiatan yang dijalankan untuk menentukan nilai dari suatu kegiatan dalam pendidikan, atau keputusan-keputusan tentang 
pengelolaan, perencanaan, tindak lanjut, dan proses pendidikan atau individu, kelompok maupun kelembagaan dalam proses pendidikan secara umum

Evaluasi pembelajaran merupakan salah satu komponen penting dalam pembelajaran atau pendidikan disisi lain evaluasi merupakan suatu proses atau suatu tindakan guna menentukan nilai peserta didik selama mengalami proses belajar mengajar selama satu periode. Penilaian dan pengukuran merupakan suatu hal yang berbeda, namun diantara pengukuran dan penilaian terdapat hal yang tidak dapat dipisahkan, evaluasi lebih menitik beratkan pada suatu tindakan untuk menentukan nilai sesuatu, sedangkan pengukuran lebih menitik beratkan pada suatu tindakan untuk menentukan kuantitas atau luas sesuatu. Jadi penilaian dilaksanakan guna memberikan jawaban dari pertanyaan "What value" sedangkan pengukuran dilaksanakan guna memberikan jawaban dari pertanyaan "How much"

Hal ini mengindikasikan bahwa evaluasi merupakan suatu kegiatan 98 yang harus ada dalam proses pembelajaran atau setiap pembelajaran. Dengan kata lain evaluasi merupakan bagian yang terpadu yang tidak dapat dipisahkan dari pendidikan atau pembelajaran. Oleh karena itu, melaksanakan kegiatan evaluasi merupakan kemampuan yang harus dimiliki oleh seorang guru. Seorang guru akan lebih mudah menguasai kemampuan evaluasi ini jika sejak dini diperkenalkan tentang kegiatan evaluasi

Jadi evaluasi pembelajaran adalah kegiatan atau proses yang menyeluruh atau berkelanjutan dan sistematis dalam rangka penjaminan, pengendalian, dan penetapan kualitas (arti dan nilai) pembelajaran berdasarkan kriteria dan pertimbangan terhadap berbagai komponen pembelajaran sebagai salah satu bentuk pertanggungjawaban seorang pendidik dalam melaksanakan pembelajarannya. Oleh karena itu, evaluasi pembelajaran dalam konteks pendidikan agama Islam adalah pengambilan keputusankeputusan yang berhubungan dengan kegiatan belajar mengajar 
dalam pendidikan agama Islam untuk mengukur sejauh mana tingkat keberhasilan dalam proses pembelajaran yang telah dilakukan tersebut. Secara implisit evaluasi pendidikan dalam Islam sudah dideskripsikan dalam Al-Qur'an sebagai asas bagi segala ilmu pengetahuan termasuk ilmu pendidikan Islam yaitu terdapat dalam Al-Qur'an surat Az-Zalzalah ayat 7-8, yang artinya : "Barang siapa yang mengerjakan kebaikan seberat dzarrah pun, niscaya dia akan melihat (balasan) nya. Dan barang siapa yang mengerjakan kejahatan seberat dzarrah pun, niscaya dia akan melihat (balasan) nya pula"

Dari pengertian diatas dapat kita ketahui bahwa evaluasi tidak hanya menilai suatu kegiatan secara insidental dan spontan, melainkan merupakan aktivitas untuk menilai sesuatu yang sistematis terencana berdasarkan tujuan yang komprehensif dan jelas

\section{Tujuan dan Fungsi Evaluasi Pembelajaran}

Tujuan evaluasi menurut pendapat Abdul Mujib dkk adalah :
1) Membangkitkan kegiatan peserta didik dalam menjalani program pendidikan.

2) Dapat mengetahui tingkat pemahaman peserta didik. Peserta didik yang tingkat pemahamannya rendah dapat diberikan perhatian khusus supaya mereka dapat mengejar kekurangannya.

3) Mengetahui kadar keefektifan suatu metode yang dilakukan guna meningkatkan pemahaman peserta didik dalam pembelajaran serta memberi mereka kesempatan untuk melatih keberanian dan mengajak mereka mengingat materi pelajaran yang pernah diberikan dan mengetahui kadar perubahan prilakunya.

4) Mengumpulkan data yang dapat digunakan untuk pengecekan yang terstruktur sebagai dasar terhadap pendidikan yang telah dicapai kemudian dibandingkan dengan tujuan yang ditetapkan sebelumnya.

Ada juga yang mengatakan tujuan evaluasi adalah mengetahui tingkat penguasaan peserta didik terhadap suatu kompetensi atau sub 
kompetensi dalam suatu pembelajaran serta mengetahui kesulitan belajar yang dialami oleh peserta didik kemudian memberikan solusi dan pengembangan evaluasi berikutnya.

Tujuan dan fungsi evaluasi pembelajaran dalam konteks Islam berfokus pada sistem evaluasi yang ditetapkan oleh Allah dalam kitabNya yaitu Al-Qur'an dan dijabarkan dalam Hadist, seperti sabda Rasulullah shalallahu alaihi wasallam tentang proses pembinaan risalah islamiyyah. Tujuan dan fungsi evaluasi pembelajaran dalam konteks Islam secara umum adalah sebagai berikut:

Pertama, Untuk memberikan ujian. Sebagaimana telah dijelaskan dalam Al-Qur'an surat Al-Baqarah ayat 155 tentang pemberian ujian bagi orang-orang beriman untuk menguji daya kemampuannya yang artinya: "Dan sungguh akan kami berikan cobaan kepadamu, dengan sedikit ketakutan, kelaparan, kekurangan harta, jiwa dan buahbuahan. Dan berikanlah berita gembira kepada orang-orang yang sabar"
Kedua, Untuk mengetahui sejauh mana tingkat pemahaman peserta didik terhadap materi yang telah diberikan oleh pendidik. Sebagaimana telah dijelaskan dalam Al-Qur'an tentang sejauh mana hasil pendidikan yang diaplikasikan Rasulullah shalallahu alaihi wasallam berdasarkan wahyu kepada ummatnya.

Ketiga, Menentukan tingkat atau klasifikasi, sebagaimana telah dijelaskan dalam Al-Qur'an tentang tingkat atau klasifikasi keimanan seseorang atau keislamannya, seperti evaluasi Allah terhadap nabi Ibrahim alaihissalam. yang diperintahkan untuk menyembelih nabi Ismail alaihissalam. putranya yang dicintai sendiri. Sebagaimana Firman Allah dalam Al Qur'an surat Al-Shaffat: 103-107 yang artinya :

"Tatkala keduanya telah berserah diri dan Ibrahim membaringkan anaknya atas pelipis (nya), (nyatalah kesabaran keduanya). Dan kami panggil dia: "Hai Ibrahim, sesungguhnya kamu telah membenarkan mimpi itu, Sesungguhnya demikian kami memberi balasan kepada orangorang yang berbuat baik. 
Sesungguhnya ini benar-benar suatu ujian yang nyata. Dan kami tebus anak itu dengan seekor sembelihan yang besar"

Keempat, Mengetahui tingkat kognisi, daya ingat seseorang terhadap materi pembelajaran yang telah diberikan oleh pendidik, sebagaimana dalam Al-Qur'an surat Al-Baqarah ayat 31 tentang evaluasi terhadap Nabi Adam Alaihissalam mengenai asma-asma yang diajarkan Allah kepadanya didepan malaikat. Adapun firman Allah SWT dalam Al-Qur'an surat Al- Baqarah ayat 31 yang artinya "Dan dia mengajarkan kepada Adam namanama (benda-benda) seluruhnya, kemudian mengemukakannya kepada para Malaikat lalu berfirman: "Sebutkanlah kepada-Ku nama benda-benda itu jika kamu memang orang-orang yang benar."

Kelima, Memberikan kabar gembira "Tabsyir/Reward" bagi peserta didik yang berprilaku baik dan memberikan hukuman "I'qab/Punishment" bagi peserta didik yang berprilaku tidak baik sebagaimana dalam Al-Qur'an surat Az-Zalzalah ayat 7-8 yang menerangkan tentang seseorang yang berbuat baik walaupun seberat "dzarrah" dia akan mendapatkan balasannya begitupun sebaliknya apabila seseorang mengerjakan kejahatan walaupun seberat "dzarrah" dia akan mendapat balasan atas apa yang dia kerjakan. Adapun firman Allah SWT dalam AlQur'an Surat Al-Zalzalah ayat 7-8 yang artinya: "Barang siapa yang mengerjakan kebaikan seberat dzarrah pun, niscaya dia akan melihat (balasan) nya. Dan barang siapa yang mengerjakan kejahatan seberat dzarrah pun, niscaya dia akan melihat (balasan) nya pula"

\section{Jenis-Jenis Evaluasi Pembelajaran}

Seorang pendidik dapat mengatahui hambatan, kelemahan, dan kemajuan peserta didik dalam melaksanakan tugasnya jika pendidik menggunakan evaluasi yang tepat sasaran, setelah itu pendidik dapat melakukan "remidial teaching" bahkan jika perlu pendidik melakukan bimbingan secara intensif kepada peserta didiknya, adapun jenis-jenis evaluasi diantaranya (Arifin, 2003:167): 
1) Evaluasi Sumatif, ialah penilaian terpadu yang sifatnya umum mengenai hasil pembelajaran yang dilakukan di akhir periode pembelajaran

2) Evaluasi Formatif, ialah penilaian yang menetapkan tingkat kemampuan peserta didik dan menentukan kemapuan yang belum dikuasainya.

3) Evaluasi Diagnostik, yaitu penilaian yang mengklasifikasikan suatu titik sesuai dengan bagiannya dalam proses belajar mengajar misalnya mengklasifikasikan peserta didik sesuai dengan latar belakang, riwayat pendidikan, kecerdasan, kesamaan minat bakat, keterampilan, metode tertentu yang hendak direalisasikan, dan penguasaan strategi belajar mengajar. Tujuan evaluasi diagnostik ialah membentuk dan mengembangkan sebuah pengertian yang sudah dikuasai oleh peserta didik dan menetapkan rencana program berikutnya.

4) Evaluasi penempatan, merupakan sebuah penilaian yang lebih menitik beratkan pada masalah- masalah yang berhubungan dengan:

a. Pengetahuan peserta didik tentang tujuan pembelajaran yang diterapkan di sekolah.

b. Pengetahuan dan keterampilan peserta didik yang dibutuhkan dalam awal proses pembelajaran.

c. Kebiasaan bekerja, perhatian, minat, dan tipe kepribadian yang cenderung berhubungan dengan metode belajar khusus contohnya belajar kelompok.

Sebagaimana telah tercatat dalam sejarah pendidikan Islam di indonesia bahwa dalam setiap akhir periode pembelajaran selalu diadakan khataman sebagai salah satu cara untuk menilai hasil akhir dari pembelajaran yang telah dilakukan di madrasah-madrasah, mengenai sejauh mana pemahaman yang telah mereka kuasai terhadap materi-materi yang selama ini telah disampaikan.

\section{B. Motivasi Belajar}

\section{Pengertian Motivasi Belajar}

Pada diri siswa, terdapat sebuah kekuatan mental yang 
dimana menurut para ahli psikologi pendidikan, menyebutnya sebagai motivasi belajar. Motivasi belajar diartikan sebagai sebuah dorongan yang ada pada diri seorang siswa untuk melakukan kegiatan-kegiatan tertentu demi untuk mencapai tujuan yang diinginkannya. Kaitannya dengan proses pembelajaran yang ada, maka motivasi belajar merupakan faktor yang sangat berpengaruh terhadap hasil belajar siswa, semakin tinggi motivasi siswa untuk belajar maka semakin berkualitas pula hasil belajar yang akan diraih. Antara motivasi dan proses belajar merupakan dua buah aspek yang tidak bisa dipisahkan, karena keduanya akan saling mempengaruhi satu sama lain, sehingga adanya kemauan seseorang untuk belajar pasti sangat dipengaruhi oleh motivasi yang hadir baik dari dalam dirinya maupun dari aspek luar yang mempengaruhi dirinya (Umi Fatonah dan Muhammad Iqbal, 2016:11).

James

menyampaikan

Whittaker

mengenai penggunaan istilah "motivasi" dalam bidang psikologi bahwa motivasi adalah kondisi atau keadaan yang dapat membangkitkan semangat yang ada pada diri manusia untuk melakukan aktivitas-aktivitasnya dalam rangka mencapai tujuan yang ditimbulkan oleh motivasi tersebut. Salah satu kunci yang dapat menghantarkan siswa pada kesuksesannya dalam belajar adalah adanya motivasi yang ada dalam dirinya. Karena dengan adanya motivasi yang ada dalam diri siswa inilah, yang akan membangkitkan hasratnya untuk belajar (Siti Amanatusifah, 2013, 13).

Sebagaimana yang telah dikemukakan MC. Donal bahwa, motivasi adalah perubahan energi dalam diri seseorang yang ditandai dengan timbulnya feeling dan reaksi dalam mencapai sebuah tujuan yang diinginkan (Tabrani Rusyan, 198:100). Hal ini berarti motivasi dapat dikatakan sebagai serangkaian usaha untuk menyediakan kondisi-kondisi tertentu sehingga seseorang itu mau dan ingin melakukan sesuatu dan bila ia tidak suka maka ia akan berusaha untuk meniadakan atau 
mengelakkan perasaan tidak suka itu.

Adapun menurut Utsman Najati, motivasi adalah sebuah kekuatan yang menggerakkan dan membangkitkan semangat makhluk hidup dalam melakukan aktivitas kesehariannya, yang akan menimbulkan adanya sebuah perubahan tingkah laku yang signifikan serta dapat mengarahkannya menuju tujuan tertentu sesuai dengan apa yang telah ditetapkan sebelumnya. Konsep tentang motivasi dalam agama Islam disebut juga sebagai fitrah yakni sebuah bentuk dorongan yang mempengaruhi manusia. Dorongan yang dimaksud dapat berbentuk insting (sifat bawaan). Sebagaimana dijelaskan dalam QS. Ar-Rum 30:

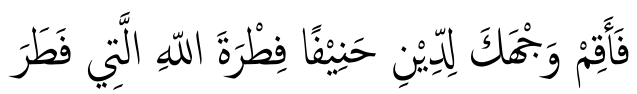

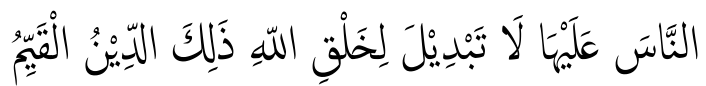

$$
\begin{aligned}
& \text { وَلكِنَّ أَكْثَرَ النَّاسِ لَا يَعْمَلُوْنَ (الروم: 30) }
\end{aligned}
$$

Artinya:

"Maka hadapkanlah wajahmu dengan lurus kepada agama Allah; (tetaplah atas) fitrah Allah yang telah 104 menciptakan manusia menurut fitrah itu. Tidak ada perubahan pada fitrah Allah.(Itulah) agama yang lurus; tetapi kebanyakan manusia tidak mengetahui” (QS. Ar-Rum 30).

Dari beberapa defenisi di atas, penulis menyimpulkan bahwa motivasi belajar merupakan dorongan atau rangsangan yang mampu membangkitkan perasaan, pikiran sehingga mampu memberikan perubahan yang signifikan terhadap tingkah laku sesuai dengan apa yang diharapkan oleh seorang motivator, dalam hal ini adalah seorang guru. Dalam proses pembelajaran PAI, motivasi sangat dibutuhkan dan menjadi salah satu faktor penentu kesuksesan seseorang dalam belajar, sebab orang yang tidak mempunyai motivasi, tidak akan mungkin melakukan aktivitas belajar, dan keberhasilan yang diinginkan dalam hidupnya pun tidak akan pernah tercapai. Oleh karena itu, motivasi sangat penting dalam proses belajar karena itu akan berpengaruh pada hasil belajarnya nanti. Hasil belajar akan lebih optimal, apabila didorong dengan adanya motivasi yang kuat untuk belajar. Makin tepat motivasi 
yang diberikan, akan makin berhasil pula pelajaran yang dipelajari.

\section{Jenis - Jenis Motivasi Belajar}

Adapun Jenis-jenis motivasi belajar dapat kita bedakan menjadi dua (2), yaitu motivasi ekstrinsik dan motivasi instrinsik (Sumardi Suryabrata, 2010:74) :

1) Motivasi Ekstrinsik

Motivasi ekstrinsik adalah dorongan-dorongan yang ada dalam diri seseorang yang didapat karena adanya rangsangan dari luar. Motivasi ini dipengaruhi oleh rangsangan dari luar yang dapat membangkitkan motivasinya untuk menyenangi atau menolak suatu objek keadaan lingkungan sosial, ekonomi pendidikan, agama dan keamanan atau harapan yang menyangkut kehidupannya.

2) Motivasi Instrinsik

Motivasi instrinsik adalah dorongan-dorongan yang muncul dari dalam diri setiap individu tersebut sendiri, karena setiap individu pasti mempunyai motivasi yang dihasilkan dari dalam dirinya sendiri untuk melakukan sesuatu, yang dimana dalam islam disebut sebagai fitrah.

\section{Fungsi Motivasi Belajar}

Menurut Oemar Hamalik ada beberapa fungsi dari motivasi belajar yakni:

1) Sebagai pendorong, yakni mendorong timbulnya perubahan tingkah laku kearah yang lebih baik.

2) Sebagai pengarah, artinya mengarahkan perbuatan seorang individu kepada pencapaian tujuan yang diinginkan.

3) Sebagai penggerak, yakni menggerakkan semangat setiap individu dalam melaksanakan aktivitas kegiatannya sehari-hari, terutama menggerakkan semangat dalam proses pembelajaran.

Adapun Sardiman mengemukakan bahwa fungsi motivasi belajar ada tiga, yaitu (Siti Amanatusifah, 2013:20)

1) Mendorong manusia untuk berbuat, jadi sebagai penggerak atau motor yang melepaskan energi. 
2) Menentukan arah perbuatan, yaitu ke arah tujuan yang hendak dicapai.

3) Menyeleksi perbuatan, yaitu menentukan perbuatanperbuatan apa yang harus dikerjakan yang serasi guna mencapai tujuan, dengan meyisihkan perbuatan-perbuatan yang tidak bermanfaat bagi tujuan tersebut.

Selain ketiga fungsi tersebut, ada fungsi lain dari motivasi belajar yang harus kita kertahui, yakni: Motivasi dapat berfungsi sebagai pendorong usaha dan pencapaian prestasi. Adanya motivasi yang baik dalam belajar, akan menunjukkan hasil yang baik. Dengan kata lain, bahwa dengan adanya motivasi, maka seseorang yang belajar itu akan dapat melahirkan prestasi yang baik.

\section{Implikasi Evaluasi Pembelajaran Pendidikan Agama Islam Terhadap Motivasi Belajar Peserta Didik Di MTs NU Banat Kudus}

\begin{tabular}{|c|c|c|}
\hline Evaluasi & & per \\
\hline pakan & salah & sat \\
\hline
\end{tabular}
pembelajaran yakni sebuah kegiatan yang digunakan untuk mengetahui sejauh mana ketercapaian tujuan pembelajaran yang telah direncanakan sebelumnya oleh lembaga pendidikan terkait (Tatang Hidayat dan Abas Asyafah, 2019:171). Adapun dalam penelitian ini kami mengambil sampel lembaga pendidikan Mts NU Banat Kudus yang merupakan salah satu lembaga pendidikan favorit di Kudus yang ikut menerapkan kegiatan evaluasi setelah proses pembelajaran dilakukan. Kami memilih lembaga pendidikan MTs NU Banat Kudus ini, karena lembaga pendidikan ini memiliki ciri khas tersendiri dalam melaksanakan sistem evaluasinya berbeda dengan lembaga pendidikan yang lain, hal itu terlihat dalam pelakasanakan PAS (Penilaian Akhir Semester), yang dimana lembaga ini tidak hanya menekankan aspek 
kognitif saja dalam penilaiannya, namun juga menekankan pada aspek psikomotoriknya, seperti; dengan adanya penilaian praktik membaca Al-Qur'an, membaca kitab kuning, praktik ibadah (wudhu, sholat), dan ibadah-ibadah lain sesuai tingkatan atau kelas masingmasing.

Sistem evaluai yang diterapkan dilembaga ini pun selalu mengalami pembaharuan dari tahun ke tahun, dari yang pada awalnya hanya menekankan aspek kognitif saja dalam penilaiannya, sekarang mulai dikembangkan dengan melibatkan aspek psikomotorik dari peserta didiknya, dengan tetap berdasarkan pada regulasi yang telah ditetapkan mengenai kegiatan evaluasi ini. Namun, meskipun sudah ada regulasi yang mengatur, pihak lembaga pendidikan tersebut seharusnya juga tetap memperhatikan bagaimana kondisi dari setiap peserta didik ketika proses evaluasi tersebut dilakukan, mengingat peserta didik merupakan objek utama dalam kegiatan evaluasi tersebut. Sehingga kegiatan evaluasi yang dilakukan oleh lembaga pendidikan tersebut dapat berjalan secara maksimal dan dapat memberikan pengaruh yang signifikan kepada setiap peserta didik.

Kegiatan wawancara ini kami lakukan dengan Ibu Dra. Hj. Dianah, M.Pd.I selaku guru mata pelajaran Qur'an Hadist kelas VIII dan IX di MTs. NU Banat Kudus, beliau menuturkan mengenai bagaimana evaluasi pembelajaran sangat berpengaruh secara signifikan terhadap motivasi peserta didik dalam belajar.

"Dilapangan masih banyak tenaga pendidik mengeluhkan peserta didiknya, orang tua mengeluhkan anak-anaknya bahwa belajar itu ketika ada penilaian baik ketika ada kegiatan penilaian/ulangan harian, penilaian tengah semester (PTS), penilaian akhir semester (PAS), atau jika ada tugas (PR). Mereka belum memaknai bahwa belajar merupakan suatu kebutuhan (Dianah, Wawancara, 2020)."

Dari hasil wawancara tersebut dapat kita simpulkan bahwa evaluasi pembelajaran yang telah dilakukan sangat berdampak secara signifikan terhadap motivasi peserta didik dalam belajar. Namun dalam kenyataannya, dilapangan masih terdapat kegiatan evaluasi 
pembelajaran yang kurang efektif, padahal evaluasi pembelajaran sangat diperlukan dalam membangkitkan motivasi belajar peserta didik. Hasil evaluasi dapat menentukan sejauh mana ketercapaian tujuan dari sebuah lembaga pendidikan. Agar evaluasi pembelajaran tersebut dapat tercapai dengan secara efektif dan efisien, maka evaluasi pembelajaran tersebut harus dilakukan sesuai dengan prosedur yang telah ditetapkan, baik dari segi penyediaan alat-alat yang didasarkan oleh prinsip-prinsip evaluasi, maupun syarat-syarat yang harus terpenuhi selama evaluasi pembelajaran dilakukan.

\section{Dengan dilaksanakannya} kegiatan evaluasi pembelajaran dalam sebuah lembaga pendidikan tersebut, maka akan dapat memberikan motivasi kepada peserta didik untuk memperbaiki, meningkatkan, dan mempertahankan prestasinya agar dapat bersaing secara kompetitif dalam tingkat-tingkat yang lebih tinggi. Adapun upaya-upaya yang dapat dilakukan seorang guru PAI, sebagaimana yang telah diterapkan dalam lembaga pendidikan MTs NU Banat Kudus untuk memotivasi peserta didik dalam kegiatan evaluasi pembelajaran adalah sebagai berikut (Dianah, Wawancara, 2020):

a. Setiap kegiatan peserta didik terkait dengan proses pembelajaran dinilai dengan angka, meliputi; penilaian kognitif, penilaian afektif, dan penilaian psikomotorik. Karena dengan dinilainya setiap kegiatan yang dilakukan oleh peserta didik, maka akan dapat menambah semangat peserta didik dalam kegiatan pembelajaran tersebut.

b. Memberikan hadiah walaupun sederhana. Karena dengan adanya hadiah peserta didik akan cenderung lebih semangat dalam melakukan sesuatu. Hadiah merupakan sesuatu yang dianggap istimewa karena diberikan atas dasar prestasi yang telah dicapai oleh peserta didik.

c. Menumbuhkan kesadaran kepada peserta didik agar menyadari akan pentingnya tugas dan menerima tantangan, menyelesaikan tugas dengan baik, karena dengan 
menyadari hal-hal kecil yang seringkali diremehkan justru yang akan membawanya kearah pencapaian yang lebih baik.

d. Memberikan ulangan. Dengan melaksanakan kegiatan ulangan seperti itu, peserta didik akan merasa termotivasi untuk giat belajar, tetapi hal itu agar tidak dilakukan terlalu sering, kalau dilakukan terlalu sering akan menyebabkan peserta didik menjadi bosan.

e. Membagikan hasil ulangan atau tugas, dengan dibagikannya hasil ulangan atau tugas peserta didik bisa mengetahui hasilnya dan dapat terjadi kemajuan menuju pada keberhasilannya. Selain itu dengan dibagikannya hasil ulangan tersebut akan membuat peserta didik merasa dihargai hasil kerja kerasnya.

f. Memberikan pujian. Pujian yang positif diberikan kepada peserta didik yang mampu menyelesaikan tugas dengan baik secara tidak langsung dapat membangkitkan harga diri dan semngat peserta didik untuk giat dalam belajar. g. Memberikan hukuman. Hukuman disini dalam pengertian bukan hukuman yang bersifat negatif, tatapi hukuman yang bersifat membangaun untuk mendisiplinkan peserta didik dalam proses pembelajaran.

Selain itu dalam awancara tersebut, ibu Dra. Hj Dianah, M.Pd.I, menjelaskan bahwa dalam melaksanakan kegiatan evaluasi pembelajaran beliau lakukan dengan melalui penilaian proses, penilaian pengetahuan, maupun penilaian hasil pembelajaran. Adapun penilaian proses dapat dilakukan dengan melalui penilaian pengamatan sikap peserta didik. Penilaian ini dilakukan ketika peserta didik melakukan kegiatan diskusi kelompok maupun ketika proses presentasi dilakukan. Dari proses diskusi tersebut beberapa sikap yang dinilai adalah: kerjasama, keaktifan, kepedulian, kesantunan, inisiatif serta ketrampilan peserta didik.

Adapun penilaian pengetahuan didapatkan dari nilai tugas yang meliputi: tugas mandiri, tugas kelompok, ataupun tugas proyek. 
Tugas mandiri dilakukan dengan cara mengerjakan lembar kerja siswa (LKS), tugas kelompok dengan cara menyusun makalah, dan tugas proyek dilakukan dengan cara misalnya mencari ayat-ayat terkait dengan bacaan tajwid. Selain itu, Ibu Dra. Hj. Dianah, M.Pd.I., juga menjelaskan bahwa MTs. NU Banat Kudus menerapkan proses evaluasi melalui Penilaian Tengah Semester (PTS) dan Penilaian Akhir Semester (PAS) seperti lembaga pendidikan yang lain.

\section{KESIMPULAN}

Dari penjelasan yang telah dipaparkan diatas maka dapat kita simpulkan bahwa, evalausi merupakan salah satu aspek terpenting dalam proses pembelajaran yang ada dalam sebuah lembaga pendidikan. Sehingga dengan begitu, kita dapat mengetahui sejauh mana ketercapaian tujuan pembelajaran yang telah dilaksanakan oleh sebuah lembaga pendidikan tersebut. Evaluasi pembelajaran yang dilakukan secara efektif dan efisien oleh sebuah lembaga pendidikan akan dapat memberikan pengaruh positif berupa dorongan/motivasi 110 dalam belajar kepada peserta didik. Agar evaluasi tersebut dapat berlangsung secara efektif and efisien, maka kegiatan tersebut harus dilaksanakan sesuai dengan prosedur yang telah ditentukan, baik mulai dari penyediaan alat-alat yang didasari dengan prinsip-prinsip dalam evaluasi maupun syaratsyarat yang harus dipenuhi selama proses evalausi pembelajaran itu dilakukan.

\section{DAFTAR PUSTAKA}

Amanatusifah, Siti. 2013. Pengaruh Tes Formatif Terhadap Motivasi Belajar Siswa Dalam Mata Pelajaran Pendidikan Agama Islam (Studi Kasus Di Sekolah Menengah Pertama Negeri 2 Batang Peranap Kecamatan Batang Peranap Kabupaten Indragiri Hulu, Skripsi, Universitas Islam Negeri Sultan Syarif Kasim Riau Pekanbaru.

Arifin, Ilmu Pendidikan Islam: Tinjauan Teoritis dan praktis berdasarkan pendekatan interdisipliner, Jakarta: PT Bumi Aksara, 2003.

Dimyati dan Mudjiono. 1999. Belajar dan Pembelajaran, Jakarta: PT. Rineka Cipta.

Hidayat, Abas Asyafah, Tatang. 2019. Konsep Dasar Evaluasi Dan Implikasinya 
Dalam Evaluasi Pembelajaran Pendidikan Agama Islam Di Sekolah. AlTadzkiyyah: Jurnal Pendidikan Islam, Volume 10, No. I.

Fatonah, Muhammad, Umi. 2016. Pengaruh Evaluasi Pembelajaran Terhadap Motivasi Belajar Bahasa Arab Siswa SMA al Ashriyyah Nurul Iman", Jurnal Educate | Vol. 1 No. 1.

H.M. Sulthon, Moh. Khusnuridlo. 2006. Manajemen Pondok Pesantren dalam Perspekftif Global, Yogyakarta: PRESSindo.

Ma'had Tahfidz Yanbu'ul Qur'an Kudus, Al Qur'anul Karim, Surah Al Zalzalah:7-8, Kudus: CV. Mubarokatan Thayyibah.

Riyadi, Nurlaili, Junaidi Hamzah. 2017.

Pendidikan

Yogyakarta: Dayun

Pelajar.

Rusyan, Tabrani. 1989. Pendekatan, Dalam Proses Belajar Mengajar, Bandung: Remaja Rosda Karya.

PR indonesia. Pasal 1 Ayat 1 UU Nomor 20 Tahun 2003 tentang Sistem Pendidikan Nasional.
Sawaluddin. 2018. Konsep Evauasi Dalam Pembelajaran Pendidikan Islam". 2Jurnal Al-Thariqah, Vol.3, No. 1, Januari-Juni.

Suharno, Ano. 2016. Evaluasi Pendidikan Perspektif Islam", Jurnal Qathruna, Vol.3, No.2, Juli-Desember.

Suryabrata, Sumardi. 2010. Psikologi Pendidikan, Jakarta: Rajawali Press.

Syar'i, Ahmad. 2005. Filsafat Pendidikan Islam, Jakarta: Pustaka Firdaus. 
Al-Mudarris : Jurnal Ilmiah Pendidikan Islam

p-ISSN: 2622-1993

Vol. 2, No. 2, November 2019, pp. 93-112

e-ISSN: 2622-1586 